Nataliya Ivanova,
Candidate of Philological Sciences (Ph. D. in Philology),
Associate Professor,
Associate Professor of Department of Foreign Languages for the Humanities,
I. I. Mechnikov Odesa National University,
(Odesa, Ukraine)
ORCID: 0000-0001-9614-9587
e-mail: nat-iva@ukr.net
Tetiana Pakhalkova-Soich,
Candidate of Philological Sciences (Ph. D. in Philology),
Associate Professor,
Associate Professor of Department of Language Training,
Kharkiv National University of Radio Electronics
(Kharkiv, Ukraine)
ORCID: 0000-0003-0459-5868
e-mail: tetiana.pakhalkova-soich@nure.ua
Oksana Prysiazhniuk,
Candidate of Philological Sciences (Ph. D. in Philology),
Associate Professor,
ORCID: 0000-0001-7357-5516
e-mail: ragsphoto@ukr.net

\title{
STRUCTURAL AND COMPOSITIONAL MODEL OF 18th CENTURY SCIENTIFIC TEXT
}

The aim of the article is to study the structure of the 18th century French scientific text "Herbier Medical. 1759" and, having considered its main logical and semantic components, ontological and functional features, to describe its structural and compositional model. Research methodology. The study revealed the integrated use of the following methods: descriptive (when inventorying and systematizing the features of the monument); structural with elements of component and distributive analysis (when studying the internal organization of the analyzed text); quantitative method (specifying the relationship between chapters with different paragraphs). Scientific novelty. It was determined that the title page "Herbier Medical. 1759" is a headline complex that conveys a textual thematic chain; the page is expositional; the introduction is a detailed description of herbal medicines' types on the next four pages; the concentrated content of the manuscript is presented on two pages in the form of a detailed classification of medicinal plants. Having studied the paragraph division of the chapters describing 21 sections of medicinal plants, the authors have identified permanent and volatile components, 
which ultimately led to the creation of a six-component composite model. Conclusions. In this article, a previously unpublished French scientific text of 1759 is introduced into scientific circulation and described, taking into account its logical-semantic organization on the basis of cognitive and communicative analysis, and ultimately contributes to the study of the history of the 18th century natural science and linguistic knowledge. We consider such studies as promising and necessary that will represent the linguoculturological analysis of phytonyms in "Herbier Medical. 1759", a systematic description of its calligraphy, etc.

Key words: the Herbarium of I. I. Mechnikov Odesa National University (MSUD), the 18th century manuscript "Herbier Medical contenant vingt et une classes de plantes usuelles dont on fait le plus frequemment usage dans la pratique de la Medecine Rangées selon les vertus qui leur sont les plus generallement reconnues", French scientific text of 1759 .

The relevance of the topic. The material for our article is the 18th century manuscript, more precisely, Travnik (1759), which has the full name "Herbier Medical contenant vingt et une classes de plantes usuelles dont on fait le plus frequemment usage dans la pratique de la Medecine Rangées selon les vertus qui leur sont les plus generallement reconnues (1759)" (further - "Herbier Medical (1759)") [7]. It is located in the Herbarium of I. I. Mechnikov Odesa National University (MSUD), which in September 2004 was included into the State Register of Scientific Objects which constitute National Treasure [1]; consequently, the study of the oldest herbarium of this collection from the standpoint of various modern directions of historical and linguistic science cannot but be recognized as relevant.

This manuscript was read only in the early XXI ${ }^{\text {st }}$ century due to the use of new digital technologies (after scanning). Now "Herbier Medical (1759)" is digitized and presented in the form of an electronic version on the website of the scientific library of I. I. Mechnikov Odessa National University in the fund of rare editions and old prints, which allows without any complications to read and to study the text generally for scientific purposes.

The aim of the article is to study the structure of this XVIII th century French scientific text, to identify its linguistic features and, having considered its main logical-semantic components, ontological and functional features, to describe its structural and compositional model.

Analysis of researches and publications. The studied text was neither published nor translated in the XVIII ${ }^{\text {th }}-\mathrm{XXI}^{\text {st }}$ centuries. Initially, only such Odesa botanists as O. Y. Bondarenko, T. V. Vasylieva, S. Kovalenko, O. S. Murashko, V. V. Nemertsalov under the leadership of S. G. Kovalenko, referred to this source, having noted its highest historic value and uniqueness $[5 ; 6]$. The researchers analyzed the floristic composition of plants presented in the XVIIIth century herbarium, and their distribution into groups. The researchers meticulously compared how, on what grounds, and for what purpose the plants described in "Herbier Medical (1759)" were used in the XVIII ${ }^{\text {th }}$ century and contemporary medicine [4]. 
Somewhat later, N. G. Ivanova has analyzed some calligraphic features of the manuscript letters [8] and has quite recently described the originality of the translation of the studied text into Ukrainian [2], drawing attention (in co-authorship with O. A. Tarasova) to some features of the translation of "Herbier Medical (1759)", taking into account the concepts of cohesion, coherence and thematic progression [3]. Such a small number of linguistic researches of this XVIIIth century manuscript allows us to consider the chosen topic relevant, well-timed and necessary.

The relevance of the study is based on the lack of comprehensive historical and linguistic researches of the manuscript "Herbier Medical Contenant vingt et une classes de plantes usuelles dont on fait le plus frequemment usage dans la praktique de la Medecine Rangées selon les vertus qui leur sont les plus generallement reconnues (1759)".

Presenting main information. "Herbier Medical (1759)" is a monochrome manuscript made on $39 \times 25$ paper, with a total volume of 254 pages, where pages of solid text alternate with pages with dried parts of plants; the latter are accompanied by nominations in French and in some cases in Latin made by the author. Plants placed on the leaves, are carefully glued with paper strips. The manuscript is characterized by good preservation and excellent neat design; pictures in the text are absent.

Deciphering the researched manuscript and preparing it for the future publication with the maximum approximation to the original (31 pages) and the list of medicinal plants (295 items) was the first stage of our work, which gave rise to our further and future research. The text is typed in a modern font and transmitted into Latin. Author's style is preserved; unstable, in many cases variable, spelling of manuscript words is shown, methods and variants of syntagmatic division of the text (division into words, selection in the text) are not changed, which is essential for further linguistic analysis of the text [2].

The manuscript "Herbier Medical (1759)" is one of those ancient texts that are distinguished by the depth and seriousness of the general design, which is manifested even in the title, which is its key structural component. It is in the title that the author motivates the ordered composition of the text, since the genre feature of the studied work is indicated - Herbier Medical, both the main idea and the further development of the work are shown in a concentrated form with reference to the number of sections of the described plants ("vingt et une classes de plantes usuelles") [7, p. 3] and the main feature taken as the basis of the classification ("les vertus qui leur sont les plus generallement reconnues") [7, p. 3]. Confirmation that the title page is considered by the author as an integral part of the text, more precisely, the "pretext", is its design, namely the fact that it participates in the general numbering and is accompanied by the Arabic numeral 1, located at the top in the center [7, p. 3]. 
The compositional structure of the studied text is clear and corresponds to the traditions of the time: almost constant use of capital letters to indicate the beginning of a new phrase and point to mark the end of the semantic segment, the division of the text into large semantic segments (paragraphs). It was found that of the 31 pages of text, only four do not begin with a new paragraph. The text itself is divided into 84 paragraphs, each of which is drawn up on a new line. The maximum number of paragraphs per page is 5 , the minimum is 1 .

Since the pagination in the original text "Herbier Medical (1759)" is centered in Arabic numerals at the top exclusively on the first ten pages, in order to optimize and simplify further work with this manuscript monument; in bibliographic references we mark the pages on the electronic version [7]. Let's continue our consi deration of the compositional structure of the studied text. On the page located on the opposite side of the title page, there is no numbering or any information.

The next page (in accordance with the numbering according to the text of the original - the third one), which is actually the first full page of the text, differs from others by the fact that its design is one paragraph. Here the author's position which reflects his observations of the surrounding world, is designated; the essence of "Herbier Medical (1759)" and its meaning are described: "Cet herbier renferme toutes les plantes usuelles que l'on employees les jours dans la pratique de la medicine" [7, p. 5]; the aim of his writing is indicated "pour pouvoir fans le fecours de ces derniers fe procurer les remedes convenables, dans les indispositions dont on peut etre affecté" [7, p. 5]; the addressee is pointed out "ceux mêmes qui ne font medecin", "ceux qui font des voyages, ou ceux qui font au service dans les troupes" [7, p. 5]; the conditions that will ensure the application of the proposed knowledge are described "au moyen de cette connoissance"; the things that could be useful are mentioned "on a tous le tems, et dans tous les lieux les plantes necessaires a nos maladies"; "on n'a pas toujours un medecin ou un un chirurgien pour en faire l'application lors que l'on en eft affecté" [7, p. 5].

So, in the studied text which is the carrier of scientific information, some special knowledge accumulated by the author has been verbalized and presented taking into account the most important pragmatic category - the "addressee factor", i.e. with an orientation towards a certain (in our case, probably not high enough) scientific level of preparedness of a potential interpreter. The successful implementation of the communicative task set by the author can be ensured through the effective organization of the text space. Therefore, this page can be considered as an introduction to the following text, emphasizing its anthropocentric orientation.

The next page of the manuscript (in accordance with the numbering according to the text of the original - the fourth one) is composed of three paragraphs.

The first line of its first paragraph shows the author's desire to attract and interest readers "Pour rendre cet herbier interessant" [7, p. 6]. In this paragraph the structure of 
the work is outlined in more details "jexpoferai à la tete de chaque classes des plantes Leur vertu, et en quoi elle Consiste, leur action fur nos parties, et La maniere de Les employer" $[7$, p. 6]. In the second paragraph, the author points out that human health and treatment are directly related to the plant world ("Les plantes font des medicamens tirés du fecond regne, qu'on nomme regne vegetal toutes leurs parties font d'usage dans la medecine") [7, p. 6], cites the constituent parts of plants ("Ces parties font Les racines, les tiges, les ecorces, Les feuilles, les fleurs, les fruits, les femences"), lists the types of herbal medicines which could be made from them ("on les employe, en infusion, en decoction, en extrait, ou en diffillation, et en poudre") [7, p. 6].

The third paragraph provides a detailed description of the methods for preparing infusion from medicinal herbs: "On ne met en infusion que les parties de plantes dont la texture, eft delicate comme font les fleur et quelques feuilles: ou bien Celles qui font fort aromatiques; parce que leur vertu qui ne consiste que dans des parties fort fubtiles fe diffippent entierement à La chaleur de L'eau bouillante: et il ne reste plus ordinairement, aprés quelles ont bouillie, qu'une eau insipide qui na plus la vertu de La plante" [7, p. 6].

The fifth page of the manuscript (numbered in the original text) starts with a detailed description of the recipe for preparing infusion: "Pour bien faire une infusion, il faut prendre une caffetiere d'environ trois ou quatre verres, L'emplir d'eau et lexprofer au feu, jusq'ace quelle commence à bouillir, enfuite on y jette deux pinceé de fleurs, de feuilles ou de plantes aromatiques; on couvre la caffetiere de fon couvercle et on la retire $d u$ feu" $[7$, p. 6]. The following are recommendations for their use, with reference to the medical practice of herbarium's author: "quand la chaleur Commence a diminuer, on verfe cette infusion dans une tasse, ou l'on a mis un peu de fucre et on La boit fur le champ: on eft certain par ce procede, d'avoir dans l'infusion toute la vertu de la plante dont on fait usages et que La plante aromatique n'en est point Evaporeé" [7, p. 6]. The following are the features of decoction preparing [7, p. $6-7]$, extraits [7, p. $6-7]$, distillation [7, p. 7], poudre [7, p. 7]. Thus, about four pages of handwritten text are dedicated to a detailed description of the types of medicinal herbal remedies and methods of their preparation.

The next semantic part is devoted to the general characteristics of medicinal herbal remedies. Their definition is given, indicating the importance of using herbal medicines ("On definit les medicamens dont les plantes font la plus grande partie; Des subftances qui etant prises interieurement, ou appliqués exterieuremt ont la faculté de changer la mauvaise dispofition de notre Corps en une meilleure") [7, p. 7], their action is described ("Les medicamens agiffent fur nos parties folides en les relachat quand elles font trop tendues; en, les refferant quand elles font trop relacheés, et en les irritant") [7, p. 8], providing the description with an example, undoubtedly based on the author's medical practice: ("Cette derniere action eft neceffaire quand il eft queftion de faire degorger les glandes: limitation que cauffe Certaines 
plantes fur les folides occasionnent une action qui ferre les glandes, et qui leur fait vuider les humeurs dont elles font engorgees") [7, p. 8].

Further, in the middle of the eighth page of the text, there is a transition from the description of medicinal values of plants to their classification by properties, which is presented by the author both clearly and visually as well as spelling and calligraphy are correct too. The new line indicates the existence of three groups of plants used in medical practice [7, p. 8].

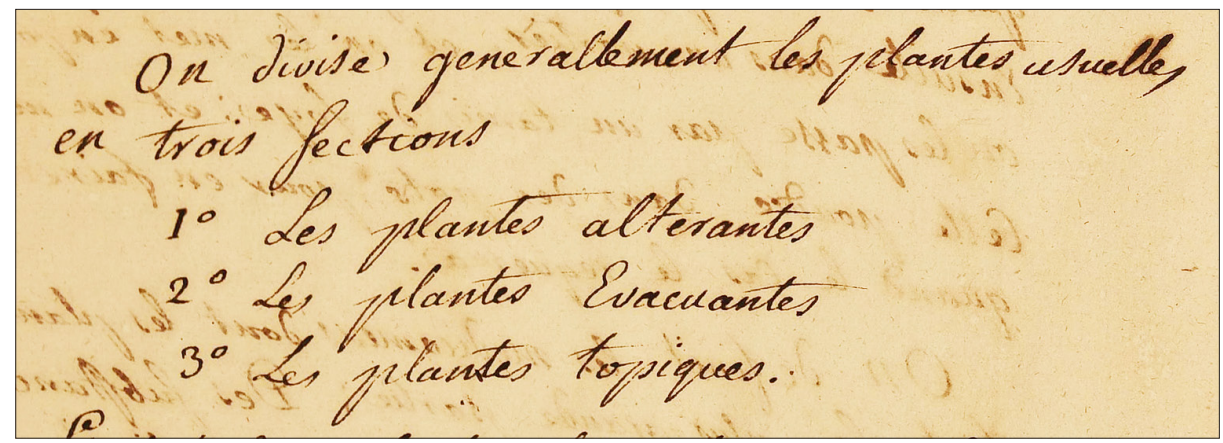

Picture 1. "Herbier Medical (1759)". Classification. Three groups of medicinal plants [7, p. 8].

In accordance with the logic of the scientific text, a short (one sentence) generalizing description of each named group is proposed and presented on a new line:

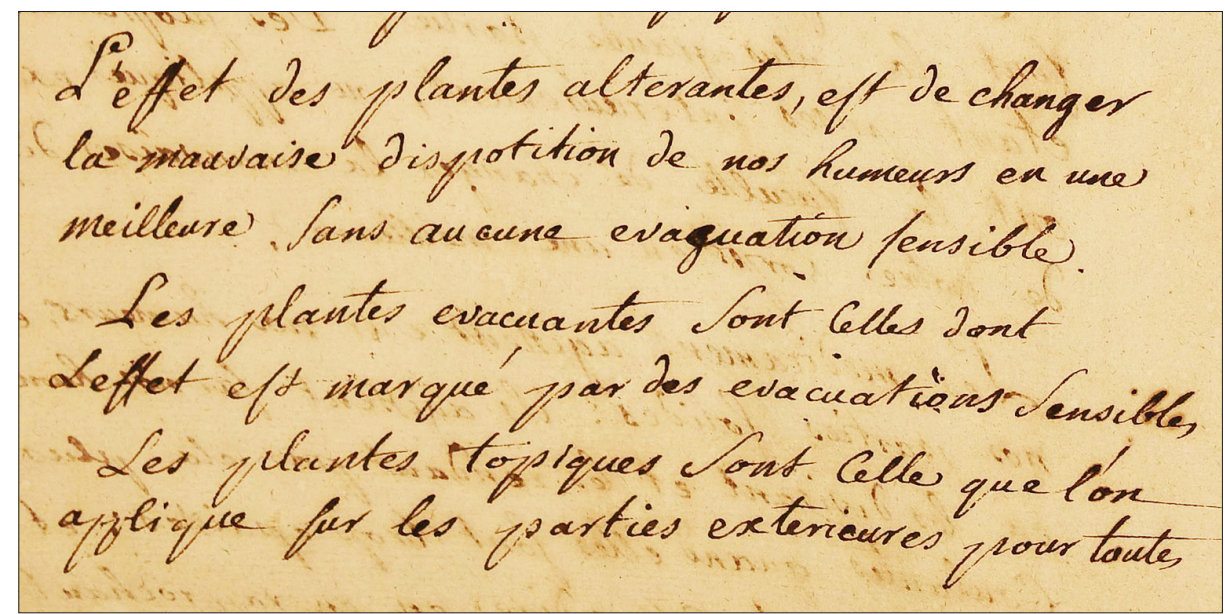

Picture 2. “Herbier Medical (1759)". Classification. Three groups of medicinal plants [7, p. 8].

The description is made up to the end of the eighth page of the original, but the last line "Les maladies qui les affectent" $[7$, p. 8] moved to the next page, which somehow violates the holistic perception of this passage of the text. So, on the ninth and tenth pages of the manuscript (numbered in the original text), further details of the classification of plant groups are presented. 
The first group is divided into 10 sections $[7$, p. 8]:

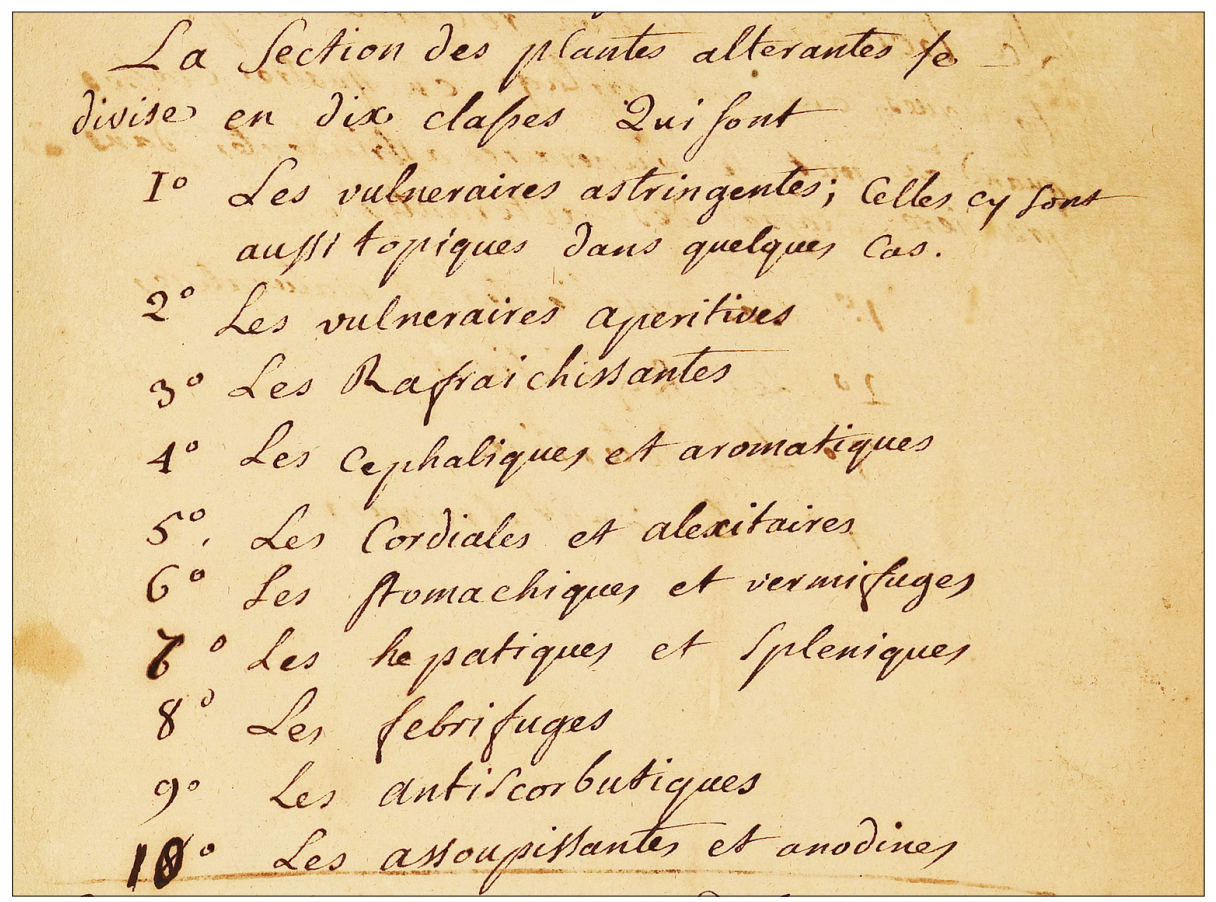

Picture 3. "Herbier Medical (1759)". The sections that make up the first group of medicinal plants $[7, p .8]$.

The second group includes 7 sections [7, p. 8]:

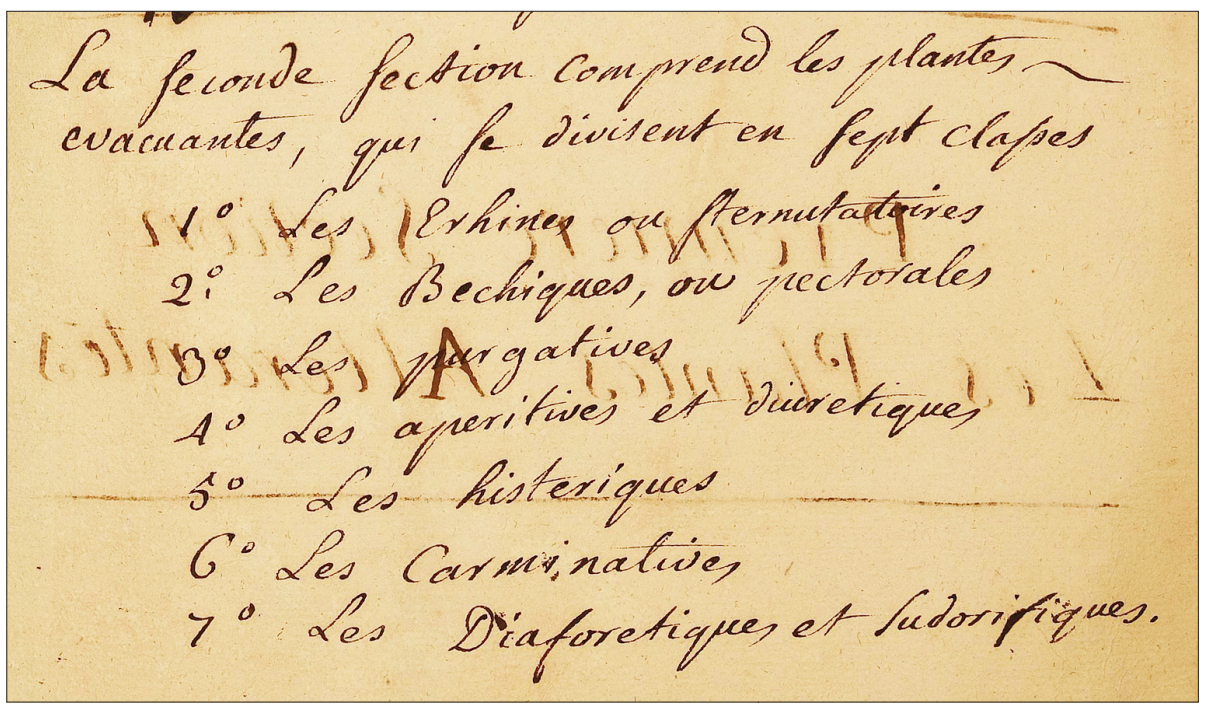

Picture 4. "Herbier Medical (1759)". Sections that make up the second group of medicinal plants $[7, p .8]$. 
The third group is formed by 4 sections [7, p. 9]:

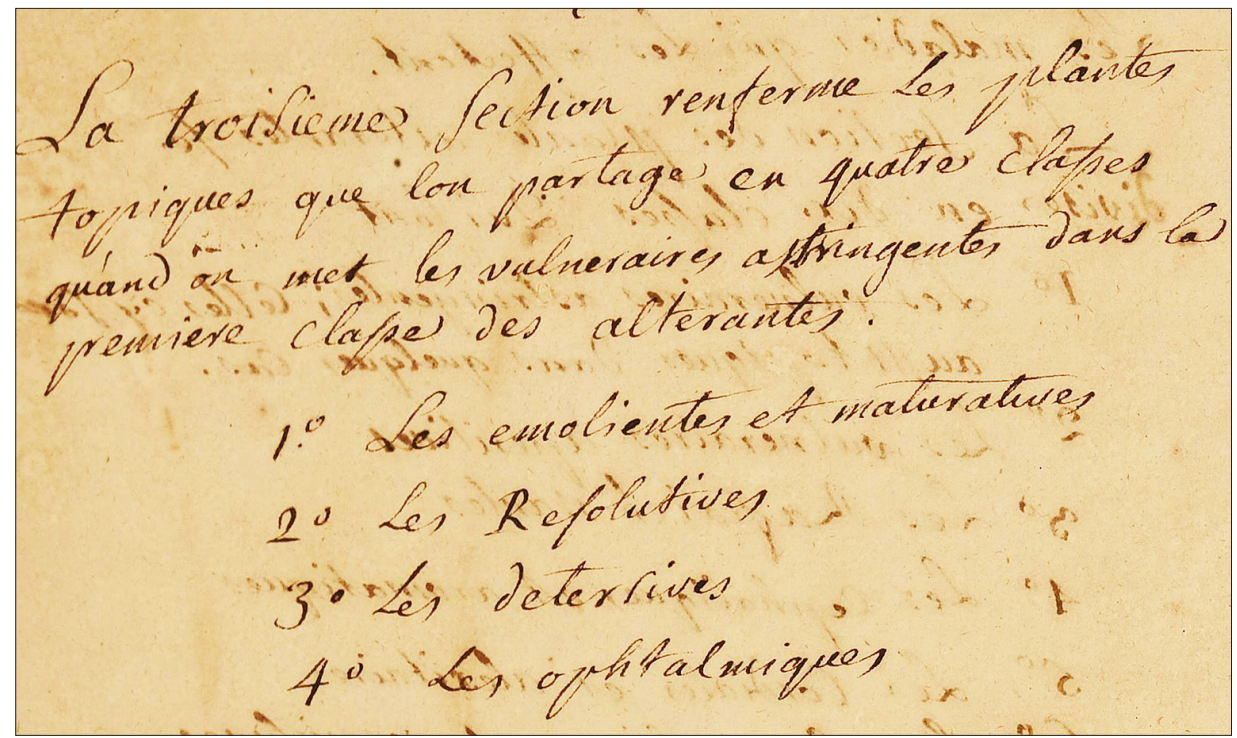

Picture 5. "Herbier Medical (1759)". Sections that make up the third group of medicinal plants [7, p. 9].

Let us note how classifications of groups and sections have been designed. First, the author uses Arabic numerals followed by a superscript, the so-called "zéro supérieur", which is the final symbol o of such Latin words as primo, secundo, tertio, quarto, quinto, sexto, septimo, octavo, nono, decimo, etc. Secondly, the initial word of the name of each plant group (and this is the definite article les) is written in a new row with a capital letter. Thirdly, punctuation marks (colon, semicolon, dash, comma), which are traditionally used in any classification, with rare exceptions, are absent. Thus, a semicolon is fixed once (in an additional remark to the first section of the first group) and twice are fixed (in a complex sentence with the relative pronoun qui in the definition of the second group and when enumerating before the conjunction ou in the second section of the second group) and dots (at the end subdivisions into classes and upon completion of the classification of the second group). We believe that exactly these three pages, which contain a numbered classification of plants, should be regarded as a non-trivial content of the manuscript. From the eleventh page of "Herbier Medical (1759)" begins the description of medicinal properties of plants [7, p. 9]. Further, the handwritten material is arranged into chapters, each of which is located on a separate page and bears a name corresponding to the title of the described section of plants. Each chapter contains graphically decorated paragraphs that reflect the logic of text's semantic relations: in four chapters (the second and sixth sections of the first group, the sixth section of the second group, the second 
section of the third group) 2 paragraphs are highlighted; in nine chapters (the first, fifth, seventh and tenth sections of the first group, the first, fourth, fifth and seventh sections of the second group, the fourth section of the third group) - 3 paragraphs; in six chapters (the fourth, eighth and ninth sections of the first group, the third section of the second group, the first and third sections of the third group) - 4 paragraphs; in two chapters (the third section of the first group and the second section of the second group) - 5 paragraphs. The abovementioned has been summarized in the diagram below, which clearly shows the numerical and percentage ratio between chapters containing different numbers of paragraphs:

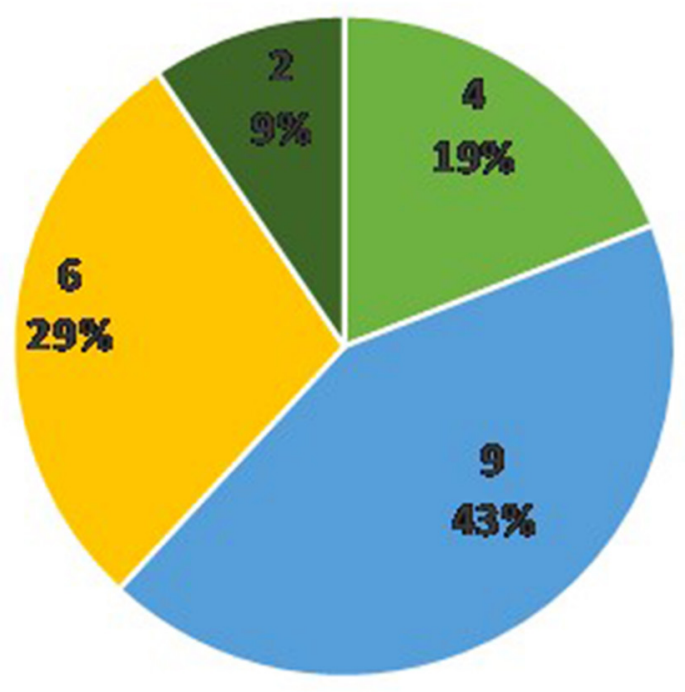

\author{
m chapters containing \\ two paragraphs \\ - chapters containing \\ three paragraphs \\ chapters containing \\ four paragraphs \\ - chapters containing \\ five paragraphs
}

Picture 6. The ratio between chapters containing different numbers of paragraphs.

Thus, in the chapters of the studied text, describing 21 groups of medicinal plants, the following linguistic pattern is observed: the number of paragraphs in them varies from 2 to 5 . Chapters with three paragraphs each make up almost half $(47 \%)$ of the total number of text's chapters; about a third of chapters (29\%) include four paragraphs; about a third $(28 \%)$ - two or five paragraphs, and the first paragraphs (19\%) are twice as many as the second ones (9\%).

Consequently, in the studied text "Herbier Medical (1759)" chapters with an average number of paragraphs ( 3 and 4) have a high frequency, chapters with a maximum (5) and minimum (2) number of paragraphs have a low frequency.

Having achieved clarity and consistency of presentation, the author clearly structures the chapters, which allowed us, when analyzing the content of the studied text, to form a six-component compositional model that reveals the same type of logical and semantic content of each chapter of the studied text. Four permanent 
components are distinguished: justification of the names of plant sections according to their functions and/or properties (1), damage to internal and external organs and/or disease (2), a description of the healing properties of medicinal plants in section (3) and methods of their use and rules of taking (4).

The information content of these components can be expanded or concretized with additional indications of the sequence and duration of therapeutic actions, the time of collecting herbs, conditions for the successful therapeutic use of plants, highlighting the value of a particular function in the body; a description of the influence made by herbal medicines on the human body, recommendations on how to use them; indication of the doctor's target attitude, description of the results of successful therapeutic use of plants of this group, indication of the condition, concomitant disease, etc. So, for example, in three chapters (the fourth section of the first group CEPHALIQUES \& AROMATIQUES [7, p. 36], in the sixth section of the first group PLANTES STOMACHIQUES \& VERMIFUGES [7, p. 50], in the seventh chapter of the first group HEPATIQUES \& SPLENIQUES) [7, p. 56] the synonymous names of the corresponding plant sections are reasonably indicated. The definition of the disease (ophtalmies) is given once, in the fourth section of the third group PLANTES OPHTALMIQUES [7, p. 148].

Two variable volatile components are fixed: warnings in the use of plants of the specified section (5), and references to the author's previous medical experience (6). Tips for the careful medicinal use of plants appear in seven chapters (in the first, third and seventh sections of the second group, in the second, third and fourth sections of the third group, and in the tenth section of the first group). We are talking about remarks about the negative consequences of violating a medical recommendation, about the wishes of careful handling with these medicaments. Information about author's preliminary medical experience takes place in four chapters (in the third and fifth sections of the second group and in the second and third sections of the third group).

As for the order of the permanent components of the text model in the chapters, in the overwhelming majority of cases it is direct. Three times (in the third, fifth and seventh sections of the second group) a transgression is observed, complicated by an inversion involving volatile components. So, in the third section of the second group PLANTES PURGATIVES [7, p. 89] at the beginning, the properties of plants and the functions they perform are indicated. Further, it is said about the existence of two subsections in the section.

Then, from a scientific point of view, the general mechanism of plants' influence is described (plants that make up this section), and the need for their careful therapeutic use is emphasized with reference to the author's preliminary medical experience. The fifth section of the second group PLANTES HYSTÉRIQUES [7, p. 107] ini- 
tially presents the properties and functions of plants; then the human organ with its functions is professionally described; then the conditions for the use of herbal medicines are indicated, their types are listed, the duration of their use is recommended; at the end, the effects associated with the successful medicinal use of the plants in this section are described. The seventh section of the second group PLANTES DIAPHORETIQUES \& SUDORIFIQUES [7, p. 120] indicates the properties and functions of the two plant species that make up this section, with an emphasis on the particular importance of their use; lists the diseases in which can be treated with the help of these plants, and diseases in the treatment of which the use of these plants is unacceptable. The end of the chapter presents a list of medicines based on them.

Let us confirm what has been said with quotations extracted from the studied text.

1. Permanent component "Justification of the names of plant sections according to their functions and / or properties":

"Ces plantes font ainsi nommeé parce quelles font employeés ..." (the first section of the first group VULNERAIRES AstRINGENTES) [7, p. 9];

"Ces plantes font ainsi nommeés parce qu'elles ont pour effet ..." (the second section of the first group VULNERAIRES APERITIVES) [7, p. 23];

"Ces plantes font ainsi nommeés parce quelles calment ..." (the third section of the first group PLANTES RAFRAICHISSANTES) [7, p. 29];

"Les plantes cephaliques font ainsi nommeé parce qu'elles ...", "On les appelle aussi aromatiques, parce que ..." (the fourth section of the first group CePHALIQUes \& AromaTIQUES) [7, p. 36];

"On nomme ainsi ces plantes parce qu'elle, ont la vertu de ..." (the fifth section of the first group CORDIALES \& AlEXITAIRES) [7, p. 44];

"Les plantes stomachiques font ainsi appelleé parce qu'elles", "On nomme encore ces plantes vermifuge a cause de ..." (the sixth section of the first group PLANTES STOMACHIQUES \& VERMIFUGES) [7, p. 50];

"Les plantes hepatiques sont ainsi appelleés parce qu'on f'en fert pour ...", "On nomme auffi ces plantes spleniques parce qu'elles ..." (the seventh section of the first group Hepatiques \& Spleniques) [7, p. 56];

"Ces plantes font ainsi nommeés, parce qu'on les employe ..." (the eighth section of the first group Plantes FeBRIFUGES) [7, p. 62];

"On appelle plantes antiscorbutiques celles dont fe fers ..." (the ninth section of the first group ANTI-SCORBUTIQUES PLANTES) [7, p. 68];

"On appelle ainsi ces plantes, parce qu'elles ..." (the tenth section of the first group десятий розділ першої групи PLANTES AfFoupiffantes) [7, p. 74];

"On appelle ainsi ces plantes, parce qu'elles ..." (the first section of the second group PLANTES ERRHINES STERNUTATOIRES) [7, p. 80]; 
"Ces plantes sont ainsi nommeé parce qu'elles ..." (the second section of the second group BeChiQues ou PeCtorales) [7, p. 82];

"Les purgatives qui agissent sur l'estomac et qui font vomir S'appellent emetiques: et celles qui purgent par les felles retiennent le nom de purgatives" (the third section of the second group PLANTES PURGATIVES) [7, p. 89];

"Ces plantes sont ainsi appellées a cause qu'elles ..." (the fourth section of the second group Plantes APERITIVES \& DiURETIQUeS) [7, p. 97];

"Cette classe renferme les plantes qui ont la proprieté d'exiter au sexe l'evacuation periodique qu'elles ont tous les mois" (the fifth section of the second group Plantes Hystériques) [7, p. 107];

"On nomme ainsi ces plantes parce qu'elles ont la vertu de ..." (the sixth section of the second group Plantes Carminatives) [7, p. 114];

"Les plantes diaphoretiques sont celles qui ont la vertue dexiter (without apostrophe) une abondante transpiration et Les sudorifiques celles qui exitent la sueur" (the seventh section of the second group Plantes Diaphoretiques \& SudorifiQues) [7, p. 120];

"Ces plantes sont ainsi appelées parce qu'elles ont la proprieté ..." (the first section of the third group PLANTES EMOLIENTES) [7, p. 126];

"On nomme ainsi ces plantes par quelle ont la faculté de ..." (the second section of the third group Plantes Resolutives) [7, p. 134];

"On nomme ainsi ces plantes parce qu'etant appliquées sur ..." (the third section of the third group Plantes VulneRaire Detersives) [7, p. 142];

"Ces plantes sont ainsi appelleé parce quelles font propres aux ..." (the fourth section of the third group PLANTES OPHTALMIQUeS) [7, p. 148)];

2. Permanent component "List of lesions of internal and external organs, and/or diseases":

"quelles font employeés avec fuccés dans les blessures tant internes qu'externes: comme playes, contusions hemoragies, crachemens, et vomissemens de sang" (the first section of the first group VULNERAIRES Astringentes) [7, p. 9];

"à la suite des coups des chutes ou des efforts violens" (the second section of the first group VULNERAIRES APERITIVES) [7, p. 23];

"la grande action des vaiffeaux fur le fang" (the third section of the first group PLANTES RAFRAICHISSANTES) [7, p. 29];

"toutes les maladies qui attaquent la tete; comme les grandes douleurs les migraines, les paralisies, les apoplexies, les stupeurs et engourdiffemens" (the fourth section of the first group CePHALIQUes \& AROMATIQUeS) [7, p. 36];

"dans les defaillances dans les fincopes, les evanoniffemens, et dans tous les cas ou le Coeur n'agit que foiblement" (the fifth section of the first group CORDIALES \& ALEXITAIRES) [7, p. 44].

And serious diseases: 
"le pourpre la fievre millaire, la petite verole, la Rougeole dans tous les cas les Mouvemens du Coeur font languiffans" (the fifth section of the first group CORDIALES \& ALEXITAIRES) [7, p. 44];

"les foibleffes de cet organe, principalement, l'on qu'il eft necessaire de lud redonner le ton qu'il a perdu par l'amas d'une quantité de limphe; qui en a trop relaché les membranes, et qui par cela luy a oté la faculté de digerer les aliments" (the sixth section of the first group Plantes Stomachiques \& Vermifuges) [7, p. 50];

"La bile f'amasse quelque fois dans le foye et en fi durcissant occasionne des obftructions et des embaras dans ce viscere", "aux embaras et aux obstructions de la rate" (the seventh section of the first group HePatiques \& SPLENIQues) [7, p. 56];

"On nomme fievre fièvre intermitente celle dont les accés reviennent et quittent alternativement telles font les fièvres tierces qui prennent de deux jour, les fievres quartes qui ne prennent que tous les deux jours de fièvre, les doubles tierce qui prennent tous les jours mais dont les accés ne durent pas 24 heures" (the eighth section of the first group Plantes Febrifuges) [7, p. 62];

"Le fcorbut consiste dans une diffolution putride du sang: Cette maladie f'annonce par des tumeurs aux gencives et par de taches fur les gencives et fur la peau" (the ninth section of the first group ANTI-SCORBUTIQUES PLANTES) [7, p. 68];

"on f'en fert ordinairement lorsque les fibres tirailleés dans les inflammations causent des grandes douleurs, et interompent le sommeil" (the tenth section of the first group Plantes AfFoupiffantes) [7, p. 74];

"Les rhumes improptement appellés rhumes de cerveau», "dans un engorgement des glandes de la membranne qui tapisse tout l'interieur du nez" (the first section of the second group Plantes ERRHINes SternUtATOIRES) [7, p. 80];

"Elles conviennent principalement dans les maladies du poumon», "la pleuvresie, La fluxion de poitrine, la pulmonie, les rhumes de poitrine" (the second section of the second group BECHIQUES OU PECTORALES) [7, p. 82];

"Il est aussi important d'uriner comme il est important de faire les autres evacuations», "Les urines supprimées ou qui ne coulent que lentement sont presques toujours suivies ...", "Ce qui occasionnent de maladies fort graves ...", "d'hydropiscie, dans le bas ventre, et de pierres de graviers et de sables, dans les reins et dans la vessie" (the fourth section of the second group PLANTES APERITIVES \& DiURETIQUES) [7, p. 97];

"La matrice qui est le piege de cette evacuation se trouve assez ordinairement obstruée dans les jeunes filles dont le temperament est delicat, et peu formé, il s'ensuit des indispositions et des maladies qui ne peuvent se dissiper, qu'en exitant cette evacuation" (the fifth section of the second group PLANTES HystÉRIQUES) [7, p. 107];

"elles ont la vertu de chaffer les vents qui l'engendre dans notre Corps", "On sçait qu'en mangeant nos aliments nous avalons beaucoup d'air, sans compter celui qui fe degage des alimans dans la digestion: Cet air fe cantonne quelquefois dans lestomac 
et cause le gonflement de cette partie. Ce qui y cause beaucoup de douleur. Lorsque les vents de meme que ceux qui sejournent dans les intestins et qui y causent des coliques venteuses tres douloureuses ne sevacuent pas d'eux memes" (the sixth section of the second group PlaNTES CARMINATIVES) [7, p. 114];

"on les employe avec succes, dans la pleuresie dans les affection cathareuses dans les ecrouelles, dans la verole, dans les Rhumatismes, La goutte, les fievres malignes", (the seventh section of the second group PLANTES DiaphoretIQUES \& SUdoRIFIQUES) [7, p. 120];

"des tumeurs dures" (the first section of the third group PLANTES EMOLIENTES) [7, p. 126];

"les tumeurs" (the second section of the third group Plantes Resolutives) [7, p. 134];

"Ces remedes conviennent, aux playes et aux uvulures ou une suppuration abbondante relache Les vaisseaux ce qui produit des chairs molafes (molasses) et baveusus, et empecha qui ne s'enforme de bonnes" (the third section of the third group PLANTES VULNERAIRE DETERSIVES) [7, p. 142];

"On appelle ophtalmies l'inflammation qui arrive aux paupieres et au blane de loeil pour la guerison de laquelle on a recour aux plantes de cette classe" (the fourth section of the third group PLANTES OPHTALMIQUeS) [7, p. 148].

3. Permanent component "Description of medicinal plants' healing properties of section":

"Leur vertu consifte à refferer ler globules du sang et a les epaiffir" (the first section of the first group VULNERAIRES ASTRINGENTES) [7, p. 9];

"elles ont pour effet d'ouvrir les pores des glandes et des vaisseaux engorgés par l'epaiffissement des humeurs" (the second section of the first group VULNERAIRES APERITIVES) [7, p. 23];

"ell aleur du fang et des humeurs qui resulte de la grande action e calment la grande ch des vaiffeaux fur le fang" (the third section of the first group PLANTES RAFRAICHISSANTES) [7, p. 29];

"toute leur vertu consiste dans un principe tres odorant, qui f'evapore a la moindre chaleur ces parties si finnes finfimment aisement dans les pores et defobruent les embaras qui caufent les maux de tete, qui font quelque fois $f$ finestes" (the fourth section of the first group CePhalloues \& Aromatiques) [7, p. 36];

"ranimer l'action du cœur et des arteres" (the fifth section of the first group CORDIALES \& ALEXITAIRES) [7, p. 44];

"il eft necessaire de luy redonner le ton qu'il a perdu par l'amas d'une quantité de limphe" (the sixth section of the first group PLANTES STOMACHIQUES \& VERMIFUGES) [7, p. 50];

"la vertu eft de brifer les matieres qui engorgent le foye et de les faire couler par les vaisseaux excretoires dans les intestins" (the seventh section of the first group HEPATIQUES \& SPLENIQUES) [7, p. 56];

"il convient avant de fe fervir des febrifuges de purger exactement ces matieres foit par vomiffement foit par les felles" (the eighth section of the first group PLANTES FEBRIFUGES) [7, p. 62]; 
"La vertu de ces plantes consiste dans leur fel sffentiel, qui a la proprieté de reperer les globules du sang et deteindre le virus qui caracterise cette maladie" (the ninth section of the first group ANTI-SCORBUTIQUES PLANTES) [7, p. 68];

"La vertu de ces plantes consiste dans une huile fetide et epaisse, qui a la proprieté de dilater considerablement le fang, de gonfler les vaisseaux et de compromer l'origine des nerfs de la le sommeill"; "elles procurent le fommeil et calment les douleurs" (the tenth section of the first group Plantes afFoupiffantes) [7, p. 74];

"rien n'eft meilleur pour degorger et faire fortir cette humeur que le tabac pris en poudre; les fels de cette plante en picotant les fibres de cette membrane, exitent une plus grande fecretion de l'humeur muqueuse; qui foulage beaucoup les parties engorgeé de cette humeur", "qu'elles ont la proprieté de faire eternuer et par la de dechanger le cerveau" (the first section of the second group PLANTES ERRHINES SteRNUTATOIRES) [7, p. 80];

"elles ont la proprieté de faciliter d'expectoration des crachats" (the second section of the second group BECHIQUES OU PECTORALES) [7, p. 82];

"Les purgatives en general n'agissent que arun fel et une huiles resineufe caustique: fon effet fe porte fur la memembranne velouteé des intestins, et en l'imtant exite une fecretion plus abbondante de l'humeur glaireuse que le filtre dans les glandes: le même effet f'étend jusqu'au reservoir la bille, ce qui dait qu'on en rend toujour dans l'operation des purgatifs" (the third section of the second group PLANTES PURGATIVES) [7, p. 89];

"qu'elles ont la proprieté d'exiter la secretion des urines", "Ces Boissons passant dans le sang et de la dans les reins, emportent avec elle, tous les obstacles qui s'opposent ala separation des urines, Charient les sables et les graviers, et les portent au de hors par les voyes urinaires" (the fourth section of the second group PLANTES APERITIVES \& DIURETIQUES) [7, p. 97];

"les plantes qui ont la proprieté d'exiter au sexe l'evacuation periodique qu'elles ont tous les mois" (the fifth section of the second group PLANTES HySTÉRIQUES) [7, p. 107];

"L'action de ces plantes est de dissoudre le sang et de faire separer une grande quantité de serosité par les pores de la peau.La sueur est dans contredit la plus grande evacuation de toute celles qui se font dans l'habitude du corp", "Cest pour quoi les sudorifiques conviennent lors que les autres evacuations ne font pas de mise" (the seventh section of the second group PLANTES DIAPHORETIQUES \& SUDORIFIQUES) [7, p. 120];

"qu'elles ont la proprieté par la mucilager qu'elles continuent de relacher et de ramolir les parties solides trop tendues, et d'angmenter la fluidité des humeurs arretées dans les parties»," Quand les tumeurs ne veulent pas prendre la voye de la resolution, on ajoute aux cataplasme faits de ces plantes, des graisses et des onguent puis, on les applique sur les tumeur et on fait par ce moyen murir la matiere, ce qui fait degenerer la tumeur en abscés qu'on est obligé ensuite d'ouvrir pour evacuer le suc" (the first section of the third group PLANTES EMOLIENTES) [7, p 126];

"elle ont la faculté de diviser, d'attenuer les humeurs éppaissis et arretées dans les tumeurs; et donnent du mouvement et augment le report (ressort) des titres et des 
vaisseaux: et disposent par ce moyen les humeurs arretées de repasser en partie dans la masse du fang et en partie par les pores de la peau" (the second section of the third group Plantes Resolutives) [7, p. 134];

"... qu'etant appliquées fur une playe ou fur unulcere Les debarassent des fucs epaissis, et des chaises baveuses, en augmantant le ressort des fibres et des vaisseaux" (the third section of the third group Plantes VuLneRAire DeteRsIVES) [7, p. 142];

"quelles font propres aux maladies des yeux" (the fourth section of the third group Plantes ophtalmiques) [7, p. 148].

4. Permanent component "Detailing of the methods of using herbal medicines, use and the rules of their taking":

"On employe les plantes, en infusion, dont on prend quatre a cinq verres par jour dans les coups les chutes \& c. On prend encore le fuc epuré de ces plantes dans les crachemens et dans les vomiffemens de sang: On fait encore avec ces plantes principalement celles qui ont le plus d'odeur une eau diffillee qu'on nomme eau vulneraire, dont on fait un grand usage tant interieurement qu'extrerreurement" (the first section of the first group VULNERAIRES AstRINGENTES) [7, p. 9];

"On f'en fert en infusion en manierre de thé en y ajoutant un peu de fucre pour en corriger l'acrimonie, on continue cette infusion pendant quelque tems, jusqu'au que l'on refente un foulagement qui annonce qu'elles ont produit leur effet" (the second section of the first group VULneRAIRES APERITIVES) [7, p. 23];

"Leur usage convient principalement dans les chaleurs de tete, foit en mangeant ces fruits murs foit en en extrayant le fuc et le buvant avec du fuère. A legard des fleuilles des plantes rafraichiffante, on f'en fert en les faisant bouillir dans beaucoup d'eau, et l'on boit cette decoction pour delayer le sang lorsqu'il eft trop epais, et que lon fe fent une grande chaleur par tout le corp" (the third section of the first group PLANTES RAFRAICHISSANTES) [7, p. 29];

"On employe ces plantes en infusion, que l'on boit par verreé, 3 a 6 par jour, ou bien on fe fert de leur eau distileé qui eft trés odorante et tres (double spelling) penetrante, en la tirant par le nez ou en appliquant des compleffes trampeés dans cette eau fur les endroits de la tete les plus douloureux On fe fert aussi de les plantes en poudre, que l'on tire par le nez comme du tabac, ou bien on en emplis des petis fachets de fatin avec du coton, que l'on applique fur la tete, on les nomme fachets aromatiques" (the fourth section of the first group CePhalloues \& AROMATIQues) [7, p. 36];

"On employe les plantes, en infusion, en firops, en etxtraits, et en diffilleés on en fait des potions avec la confection ohiacinte, d'alkerme, ou avec le diascordium" (the fifth section of the first group CoRDIALES \& ALEXITAIRES) [7, p. 44];

"il convient avant de fe fervir de ces plantes de vuider l'estomac par des purgatifs appropriés; ensuite on prend quelques verres d'infusion de ces plantes foit dansl'eau bouillante, ou dans le vin blanc, pendant lespace de quelque jours", "on f'en fert dans ce cas, 
comme dans le precedent en infusion, et en poudre" (the sixth section of the first group Plantes Stomachiques \& Vermifuges) [7, p. 50];

"On employe ces plantes en decoction, en extrait et en poudre; on en continu l'usage le plus long tems qu'il eft poffible", "on les employe de la meme maniere" (the seventh section of the first group HePATIQUES \& SPLENIQUeS) [7, p. 56];

"Ensuite on prend les febrifuges en decoction, en extraits et en sirop dont on continue I'usage jusqu'a parfaite guerison" (the eighth section of the first group PLANTES FEBRIFUGES) [7, p. 62];

"On employe ces plantes en decoction, en extraits et de fic epuré. On fait encore avec ces plantes un vin antiscorbutique fort recommandable pour cet effet on prend ces plantes, on les coupe par petis morceaux et on fait usage de ce vin le plus long tems qu'il eft poffible" (the ninth section of the first group ANTI-SCORBUTIQUES PLANTES) [7, p. 68];

"On employe ces plantes interieurement et exterieuement: de celles que l'on prend interieurement dont on fait une decoction avec ou un firop il ny a gueres que le pavot" (the tenth section of the first group Plantes afFoupiffantes) [7, p. 74];

"IL ferait bon de ne faire usage de cette plantes que quand le besoin le requiert, pour en reffentir l'effet" (the first section of the second group Plantes ERRHines Sternutatolres) $[7$, p. 80];

"On Les employent en infusions, en decoctions et en sirop", "Les infusions et decoctions etant bues amplement passent dans le fsng et delayent celuy qui eft ftagnant dans le poumon, fonde la limphe gropieres qui a peine s fe feparer du sang pour former les crachats: Et les ferops (firops) facilitent lexpulsion des crachats que les infusions ont delayés precedement", "Mais pour que ces remedes agissent avec toute l'efficacité qu'on attend, il eft important de faire preceder la faigneé, et les autres fecours auxilliaires" (the second section of the second group BECHIQUES OU PECTORALES) [7, p. 82];

"on se sert efficacement des plantes diuretiques en infusion et en decoction"," on boit abbondamant, aprés y avoir mis un peu de nitre", "au grand foulagement de ceux qui sont les porteurs de ces facheuses maladies" (the fourth section of the second group Plantes Aperitives \& DiURetiques) [7, p. 97];

"on employe ces plantes en infusion en decoction en eau dissilleé, en extrait (extrai$c t$ ?), en firop et en poudre"; "on en continue l'usage, jusqu'a ce que l'evacuation revienne", "Pour cet effet on à coutume aprés avoir fait preceder la saignée du pied et la purgation, de les mettre a l'usage des plantes hysteriques ..." (the fifth section of the second group Plantes HystériQues) [7, p. 107];

"on en procure l'evacuation par lusage des plantes carminatives: on les fait bouillir dans l'eau et on met la decoction dans une seringue ensuite on la prend en lavement: $\mathrm{Ce}$ lavement cause toujour l'evacuation de grosses matieres, qui fait jour aux vents et qui les obligent a l'evacuer a deux tour. Pour les vents dans l'estomac: on fait une infusion de ces plantes ou de leur semences que l'on bois par verrée et qui procure du soulagement" (the sixth section of the second group Plantes Carminatives) [7, p. 114]; 
"On se sert de ces plantes en infusion, en decotion et en poudre, de meme qu'en eaux dissillées" (the seventh section of the second group Plantes DiAPHORETIQUeS \& SUdORIFIQUES) $[7$, p. 120];

"On s'en sert en decoction et en cataphasme" (with an explanation of the purpose of such application) "pour ramolir les tumeurs dures afin de parvenir a les faire dissoudre par la voye de la resolution" (the first section of the third group PLANTES EMOLIENTES) [7, p. 126];

"que l'on met en poudre et dont on fait des cataplasmes", "quand il est question de ramolir l'humeur et de la resoudre en même temps", "on les employe dabord melés avec des Emoliens», "ensuite on les employe seule", "on fe fert dabord des Emoliens feuls, ensuite, des emoliens et des resolutifs melés ensembles: aprés calades refolutifs feuls qui achevent la guerison" (the second section of the third group PLANTES RESOLUTIVES) [7, p. 134];

"On employe ces plantes en decoction et en infusion, quelquefois en poudre en en melant avec les emplatres et autres onguents" (the third section of the third group PLANTES VULNERAIRE DETERSIVES) [7, p. 142];

"Ensuite on se sert avec succes des plantes ophtalmiques en infusion, en decoction ou en eau disssllée", "mais avant de f'en fervir il faut avoir fait preceder la faignée et les boissons delayantes et rafraichissantes" (the fourth section of the third group PLANTES OPHTALMIQUES) [7, p. 148].

5. Volatile component "Precautions in the use of plants of the above mentioned section as regards possible complications and / or negative effects on the body":

"Alegard des autres plantes assoupiffantes, l'usage interieur eft trés dangereux, il cause des allienations d'esprit des folie et quelque fois la mort: il n'eft donc prudent que de f'en fervir alexterieur (together without an apostrophe) en decoction ou de fuc epuré, encore ne faut-il le faire qu'avec beaucoup de reserve" (the tenth section of the first group PLANTES AfFoupifFANTES) [7, p. 74];

"I'usage habituel que l'on fait, empeche le plus fouvent de le ressentir" (the first section of the second group Plantes ERRHINES SteRnUtATOIRES) [7, p. 80];

"On ne doit jamais utiliser fe fervir de purgatifs violens ni desirer faire beaucoup de selles quand on le purge", "Comme auffi on ne doit jamais fe purger que l'on ne foit preparé deux jours avant par une ample boiffon" (the third section of the second group Plantes Purgatives) [7, p. 89];

"Mais on doit s'en abstenis quand la fievre est forte et surtout quand l'inflamation de quelque partie est imminente n'y dans les grandes douleurs" (the seventh section of the second group Plantes Diaphoretiques \& SUdorifiques) [7, p. 120];

"car si on les appliquois dabord feuls il y auroit de l'inconvenient" (the second section of the third group Plantes Resolutives) [7, p. 134];

"mais on ne doit enfaire usage qu'avec beaucoup de circonspection" (the third section of the third group PLANTES VULneraire Detersives) [7, p. 142]; 
"on bassine les yeux le plus frequamment qu'il est possible, ayant soin d'en faire entrer dans l'oeil", "l'on couvre bien le tout de crainte que l'air ny fasse de mauvaise impression" (the fourth section of the third group PLANTES OPHTALMIQUeS) [7, p. 148];

6. The volatile component "Recalling the author's prior medical experience":

"il arrive fouvent que le purgatif ne trouvant plus de matieres pour agir porte son action fur la velouté des intestins, le dechire, ce qui exite des coliques, des fuperpurgation et des hemoragies dangereuses" (the third section of the second group PLANTES PURGativES) [7, p. 89];

"Ces plantes outre la vertu que nous leur attribuons ici ont encore celle de fortifier lestomac et de rendre l'appetit que la suppression des regle avoit oté, ou depravé" (the fifth section of the second group PLANTES HYSTÉRIQUES) [7, p. 107];

"ainsi quand on veut traiter une tumeur par la voye de resolution" (the second section of the third group Plantes ResolUtives) [7, p. 134];

"On fait quelquefois des injections dans des ulceres profonds ou qui penetrent dans la tete dans la poitrine au dans le bas ventre: en melant de la decoction de ces plantes dans une seringue, et poussant doucement cette liquear" (the third section of the third group Plantes VulNeRAire Detersives) [7, p. 142].

Scientific novelty. As a result of the conducted research, it was determined that the title page of "Herbier Medical. (1759)", being a heading complex, is a pretext preceding the text thematic chain; the page, which is designed as a whole, in one paragraph, "opening" the text, is expositional; the introduction is a detailed description of the types of herbal medicinal products and methods of their preparation on the next four pages of handwritten text; the concentrated content of the manuscript, its core, is presented on two pages of text in the form of a detailed classification of medicinal plants.

As a result of studying the structure and paragraph division of chapters describing 21 sections of medicinal plants, the authors revealed permanent and volatile components, which ultimately led to the creation of a six-component compositional text model (with four constants and two variables). On this basis, it has been determined that the mission of "Herbier Medical (1759)" consists in the medicinal (medical) use of plants and / or components, and not in the description of the structure of medicinal plants. Consequently, the main semantic and thematic focus of "Herbier Medical (1759)", compiled by a naturalist physician, - treatment of various human diseases with well-known herbs.

Conclusions. In this article, a previously unpublished French scientific text of 1759 is introduced into scientific circulation and described, taking into account its logical-semantic organization on the basis of cognitive and communicative analysis, which makes a certain contribution to the study of the diachronic development and functioning of the lexical-grammatical and syntactic system of the French 
language and ultimately contributes to the study of the history of XVIII ${ }^{\text {th }}$ century natural science and linguistic knowledge. We consider such studies as promising and necessary that will represent the linguoculturological analysis of phytonyms that appear in "Herbier Medical. (1759)", a systematic description of its calligraphy, lexical-semantic and syntactic features, etc.

\section{Список використаних джерел}

1. Державний реєстр наукових об'єктів, що становлять національне надбання. Реєстр 4 (доповнений). Додаток до постанови КМУ від 22 вересня 2004 р. № 1241. Наукові об'єкти, що становлять національне надбання. Київ, 2004. 15 c. URL: http:// www1.nas.gov.ua/infrastructures/NationalProperty/Documents/Der_Rejestr_NN.pdf (дата звернення: 17.10.2020).

2. Іванова Н. Г. Особливості перекладу франкомовних фахових текстів із флористичною тематикою XVIII-го століття. Кваліфікаційна робота. XНУ ім. В. Н. Каразіна. Харків, 2020.

3. Іванова Н. Г., Тарасова О. А. Когезія, когерентність та тематична прогресія: франкомовний науковий манускрипт XVIII століття // Modalități conceptuale de dezvoltare a științei moderne: colecție de lucrări științifice « $\Lambda$ 'ОГО științifice și practice internaționale. Vol. 3, 20 noiembrie 2020. Bucureşti, România, 2020. C. 101-102.

4. Коваленко С. Г., Бондаренко О. Ю. Скарби гербарію Одеського національного університету ім. І. І. Мечникова. Травник XVIII сторіччя // Вісник Одеського національного університету. Одеса, 2005. Т. 10. Вип. 5. С. 191-198.

5. Коваленко С. Г. Гербарій Одеського національного університету ім. І. І. Мечникова // Гербарії України. Index Herbariorum Ucrainicum / ред.-уклад. Н. М. Шиян. Київ, 2011. С. 222-233.

6. Мурашко О. С., Немерцалов В. В. Рослини-символи Старого та Нового світу в бібліографічних джерелах // Вісник Одеського національного університету. Одеса, 2012. T. 17. № 1 (7). C. 105-138.

7. Herbier Medical contenant vingt et une classes de plantes usuelles dont on fait le plus frequemment usage dans la pratique de la Medecine Rangées selon les vertus qui leur sont les plus generallement reconnues. Manuscript. 1759. 156 p. URL: http://rarebook.onu.edu.ua:8081/handle/store/5926 (accessed 30.01.2020)

8. Ivanova N. Herbier manuscrit du XVIllème siècle: Particularités de sa calligraphie [XVIII th century handwritten herbarium. Features of its calligraphy]. INTERTEXT. Nr. 3/4 (39/40). 10th year. Chişinău, ULIM, 2016. Pp. 112-126. 
Наталія Георгіївна Іванова,

кандидат філологічних наук, дочент,

дочент кафедри іноземних мов гуманітарних факультетів,

Одеський національний університет ім. І. І. Мечнікова

(Одеса, Україна)

ORCID: 0000-0001-9614-9587

e-mail:nat-iva@ukr.net

Тетяна Володимирівна Пахалкова-Соіч,

кандидат філологічних наук, дочент,

дочент кафедри мовної підготовки,

Харківський начіональний університет радіоелектроніки

(Харків, Україна)

ORCID: 0000-0003-0459-5868

e-mail: tetiana.pakhalkova-soich@nure.ua

\section{Оксана Ярославівна Присяжнюк,}

кандидат філологічних наук, дочент,

дочент кафедри іноземних мов гуманітарних факультетів,

Одеський національний університет ім. І. І. Мечнікова

(Одеса, Україна)

ORCID: 0000-0001-7357-5516

e-mail: ragsphoto@ukr.net

\section{Структурна та композиційна модель наукового тексту XVIII століття}

Метою статті $\epsilon$ дослідження структури франкомовного наукового тексту XVIII ст. «Herbier Medical contenant vingt et une classes de plantes usuelles dont on fait le plus frequemment usage dans la pratique de la Medecine Rangées selon les vertus qui leur sont les plus generallement reconnues. 1759», розгляд його основних логікосмислових компонентів з виявленням онтологічних і функціональних ознак та описання структурно-композиційної моделі. Методологія дослідження. Застосовано комплексне використання таких методів: описового (при інвентаризації та систематизації особливостей пам'ятки); структурного з елементами компонентного та дистрибутивного аналізу (протягом вивчення внутрішньої організації манускрипту); кількісного (для уточнення співвідношення між частинами з різним абзацним членуванням). Наукова новизна. Визначено, що титульна сторінка «Herbier Medical. 1759» $є$ заголовним комплексом, який передає текстовий тематичний ланцюжок; цілісно оформлена сторінка, що «відкриває» текст, $є$ експозиційною; інтродукцію становить детальне описання видів лікарських трав'яних засобів на наступних чотирьох сторінках; сконцентрований зміст манускрипту представлено на двох сторінках у вигляді докладної класифікації лікарських рослин. Внаслідок аналізу абзацного членування частин, що характеризують 21 розділ лікарських рослин, виділено перманентні та волатильні компоненти, що призвело до створення шестикомпонентної композиційної моделі (з чотирма константами та двома змінними). 
Висновки. Статтею залучено до наукового обігу та описано, з урахуванням його логіко-смислової когнітивної організації, поки ще не опублікований франкомовний науковий текст 1759 року; зрештою, це сприяє вивченню історії природничонаукових і лінгвістичних знань XVIII століття. Перспективними вважаємо подальші дослідження щодо лінгвокультурологічного аналізу фітонімів «Herbier Medical. 1759», системного опису його каліграфії тощо.

Ключові слова: гербарій Одеського національного університету імені І. І. Мечникова, рукопис «Herbier Medical contenant vingt et une classes de plantes usuelles dont on fait le plus frequemment usage dans la pratique de la Medecine Rangées selon les vertus qui leur sont les plus generallement reconnues. 1759», франкомовний науковий текст XVIII століття. 